DOI: https://doi.org/10.35387/ucj.2(2).2020.7-12

\title{
NATALIYA AVSHENYUK
}

\section{UNESCO ROLE IN ADULT EDUCATION POLICY DEVELOPMENT AT THE END OF THE XX CENTURY - THE BEGINNING OF THE XXI CENTURY}

\begin{abstract}
The article is based on an integrated analysis of key UNESCO documents (Recommendations of the International Conference on Adult Education CONFINTEA (1985, 1997, 2003, 2009), Global Reports on Adult Learning and Education $(2009,2013,2016,2019)$ that outlines the impact of evidence-based research on educational policy in supporting the development of educational policy in adult learning in the global educational environment at the end of the XX and at the beginning of the XXI century. It is found that the development of adult education is necessary due to the dynamics of social, scientific and technological improvement; changes in the content and nature of work and social activities of people; increased free time and opportunities for its effective use; labor market demands, the main requirements of which are to increase the competence and skills of the professional. Adult involvement in lifelong learning not only encourages meeting own needs, but also ensures self-fulfillment to a free choice of a place, time and a pathway of improvement. It is proved that since the 1970s up to now UNESCO has played a key role in shaping and disseminating the concept of lifelong learning in education policy. The concept, in essence, involves the restructuring of the existing education system and use of educational perspectives of adults externally the traditional education system in order to influence the development of different social groups and individual development of each person. The world has accumulated considerable meaningful experience in the development of the theory and practice of adult education, which is accumulated, disseminated and implemented through the activities of international organizations on a global scale, including UNESCO. This international organization generates ideas and builds educational policies that are based on reliable statistics and the results of global empirical research.

Key words: lifelong learning, adult education, international educational policy, critical pedagogy, UNESCO, CONFINTEA.
\end{abstract}

\section{РОЛЬ ЮНЕСКО В РОЗВИТКУ ПОЛІТИКИ ОСВІТИ ДОРОСЛИХ КІНЦЯ ХХ - ПОЧАТКУ ХХІ СТОЛІТТЯ}

Анотація. У статті проаналізовано ключові документи ЮНЕСКО (Рекомендації Міжнародної конференції з питань освіти дорослих CONFINTEA (1985, 1997, 2003, 2009), Глобальні доповіді про навчання та освіту дорослих (2009, 2013, 2016, 2019), що окреслюють вплив науково обгрунтованих досліджень на освітню політику та підтримку ї̈ розвитку на шляху навчання дорослих у глобальному освітньому середовищі наприкінці ХХ та на початку ХХІ століття. Встановлено, що розвиток освіти дорослих відбувається через динаміку соціального, науково-технічного вдосконалення; зміни у змісті та особливостях праці, соціальної діяльності людей; збільшення вільного часу та можливостей його ефективного використання. Основними вимогами є підвищення компетентності та вмінь професіонала. Залучення дорослих до навчання впродовж життя не лише стимулює задоволення власних потреб, але й забезпечує вільний вибір місия, часу та шляху професійного вдосконалення. Доведено, що з 1970-х років дотепер ЮНЕСКО відіграє ключову роль у формуванні та розповсюдженні концепції навчання впродовж життя в освітній політиці. Ця концепція передбачає перебудову існуючої системи освіти з використанням освітніх перспектив дорослих на противагу традиційній системі освіти з метою впливу на розвиток різних соціальних груп та індивідуальний розвиток кожної людини. Світовий досвід у розвитку теорії та практики освіти дорослих накопичується, поширюється та впроваджується завдяки діяльності міжнародних організацій у глобальному масштабі, зокрема ЮНЕСКО. Ця міжнародна організація генерує ідеї та формує освітню політику, яка базується на надійній статистиці та результатах глобальних емпіричних досліджень.

Ключові слова: навчання впродовж життя, освіта дорослих, міжнародна освітня політика, критична педагогіка, ЮНЕСКО, CONFINTEA.

Introduction. UNESCO is one of the few international organizations to promote democratic adult education programs despite the globally recognized economic feasibility of lifelong learning for adults at the beginning of the XXI century. In the global education envi- ronment, UNESCO is the only international organization where the global educational community participates, in contrast to the OECD and the World Bank, which unite mainly industrialized countries and cover much narrower range of educational issues. Since 1945 
UNESCO's activities in the field of lifelong learning have been aimed at shaping a new international order, affirming the main role of education in the development of personality and strengthening its social ties.

The starting point in the history of UNESCO's international educational policy on adult education is considered to be an adoption of the «Recommendations on the Development of Adult Education» (hereinafter - the Recommendations) at the UN General Conference on Education, Science and Culture in Nairobi in 1976 (UNESCO, 1976). It was in this document that the concept of «adult education» was substantiated on a global scale, the key guidelines of its formation were formulated and the basic principles of development were defined. Today, these are widely quoted classic statements that are used by scholars and practitioners in the adult learning and form the theoretical basis of this field of education. A study of this document shows that an adult education is becoming an integral part of the education system of the twentieth century in accordance with the principles of lifelong learning. The Recommendations emphasize, in particular, the responsibility of countries consider the importance of adult education as a special optimizing component of the entire education system and its promotion as an element of socio-cultural and economic development.

However, back in 1949, the International Conference on Adult Education - CONFINTEA (hereinafter - the Conference) was launched UNESCO in Elsinore, Denmark, and has been held once every 12 years since 1960: 1960, Montreal, Canada), 1972 (Tokyo, Japan), 1985 (Paris, France), 1997 (Hamburg, Germany), 2009 (Belem, Brazil). The author considers the evolution of UNESCO's strategic initiatives in the development of educational policy of adult learning and education through the recommendations approved in the resolutions of these Conferences.

Our study shows that in the second half of the 1980's and mid 1990's researchers and managers of adult education studied complex methodological issues. In the course of general theoretical study of the research problem conceptual frameworks were revealed, the scope of socio-economic, political, organizational, and administrative context of its implementation was studied. In 1985 the Fourth Interna- tional Conference on Adult Education - CONFINTEA IV was held in Paris (France) where the resolution noted significant changes in its development, namely the expansion of structural ties (based on vertical and horizontal integration of education forms) between adult education and other components of lifelong learning systems; general commitment to international cooperation with clearly defined priority goals; creation of new research centers and international organizations (Fourth, 1986).

The Fifth International Conference on Adult Education - CONFINTEA V in Hamburg (Germany, 1997), attended by Ministers of Education, Culture and Information from 140 countries, as well as UN and UNESCO leadership, was a turning point in the history of international recognition of the importance of adult education as a unique way to ensure the sustainable development of societies and direction. As a result of the Conference, the participants developed and approved the «Hamburg Declaration on Adult Education», were the importance of the following was emphasized: 1) complement the content of education at different levels and levels in the context of lifelong learning; 2) guarantee the right of an adult to study in a form convenient for him / her; 3) development of state and non-state social programs for the improvement of adult education (UIE, 1997).

The next contribution to the development of international strategies of adult education was the Sixth International Conference - CONFINTEA VI, held in December 2009 in Belem (Brazil). Representatives of 144 participating countries approved the Belem Framework for Action, which focused, among other issues on the diversity of forms and areas of adult education, on the recognition of non-formal education as a formal form of lifelong learning (UIL, 2009). This meeting gave new dynamic to the study of the most important issues of adult learning (literacy, equal access to basic and lifelong learning), which are considered key in solving global human problems, namely: democracy, peace and human rights, preserving diversity, providing education for all and education for sustainable development of society, conflict resolution, development of labor resources.

As can be observed, the Conference is an important platform at the international level 
for political dialogue and new commitments of adult education, namely: literacy, non-formal education and training, formal recognition of lifelong qualifications, in particular within non-formal and informal education.

The Aim of the Study. On the basis of meta-theoretical analysis of fundamental studies on critical pedagogy (J. Habermas, T. McCarthy, P. McLaren), and the use of a method of integrated analysis (R. Torraco) of scientific, educational and methodical literature on certain topics were reviewed, studied, analyzed critically and synthesized literature to generate new conceptual ideas and perspectives of a research issue.

Theoretical Framework and Research Methods. It was noted that critical theory in the wider sense does not mean a specific «theory or holistic research program, but involves a variety of (theoretical) discourses», different «in origin, content, direction». Such discourses are usually called psychoanalysis, poststructuralism, feminism, multiculturalism, the study of racism, ethnocentrism, colonialism, and so on. Critical theory asserts «as the most effective means of the ideological mechanisms involved in the production of knowledge on the "reverse side of education» (Furs, 2006). P. McLaren considered that, according to the critical theory, formal education in modern society trains students for two main roles: dominance or subordination in the existing social structure (Frumin, 1998). The main interest of critical pedagogy theorists (A. Gramsci, P. McLaren, D. Kellner) is creating conditions for overcoming such stereotypes and shaping a society based on just social relations. They believe, that a person can transform both himself and social institutions by creating various alternative structures (including alternative educational institutions) (Kellner, 2003). The study showed that the outlined principles of critical pedagogy in the second half of the XX century became the basis for the creation and establishment of formal and non-formal adult education in UNESCO political and strategic discourses.

Results. Modern strategies of global development are based on the principles of comprehensive development of human potential where the role of education is constantly growing and becoming dominant. At the beginning of the XXI century determinants of society are the conditions that mainstream the development of adult education, in particular the rethinking of its basic guidelines, because our time is characterized by extremely active processes of obsolescence and, accordingly, the renewal of knowledge. Such contexts are: adoption of international legal acts on adult education; perspective of global, regional and local educational environment; building a positive image of adult education; prioritizing humanistic education by the pedagogical community; development of the concept of balanced educational policy; development of democratic educational programs.

These processes stimulate the acquisition of new knowledge and competencies to ensure effective social and professional development of a person throughout life. To solve the issues of the society adult education should provide opportunities that will allow a person: to learn to know, that is, to provide the expertise for understanding what is happening in the world; learn to make the necessary changes in the environment; learn modern way to participate in all spheres of life and collaborate with other people; after all, just learning to live in a diversified, fast-paced, multitasking world. From this point of view, adult education is considered a leading factor in ensuring national security in the context of globalization, «the key to the XXI century» (International Conference on Adult Education, 1997).

UNESCO, as a leading United Nations education organization, helps countries to conceptualize and implement the task of education systems modernization at all levels, including adult education in the formal, non-formal and informal education. At the international level in order to assist all countries participation in international joint activities to ensure quality lifelong learning for their citizens, UNESCO disseminates experience in education planning and management; generates ideas and builds educational policy based on reliable statistics and the results of empirical research; formulates the need and promotes activities to ensure adult education of an inclusivity and innovation by implementing a coherent educational policy and an agreed action plan. Analytical processing of information, theoretical research, determination of strategic plans of international educational policy is carried out by UNESCO within the specially created institutions, including the International Institute 
for Educational Planning and the Institute for Lifelong Learning (Organization, 2002).

Leading analysts of these institutions (C. A. Torres, K. Medel-Anonuvo, R. Desjardins) agree that all UNESCO member countries face two very important challenges in the development of adult education, namely: 1) development of critical importance of research and scientific knowledge of adult education and 2) the development of effective management and governance of adult education, which are inextricably linked (MedelAnonuevo, Torres, \& Desjardins, 2011).

In our opinion, the study of the phenomenon of interdependence of research and building of effective educational policy, which in academic circles of foreign countries is called «evidence-based policy research» by C. MedelAnonuevo, C. A. Torres, R. Desjardins; "evidence-informed policy research" by T. Burns, T. Schuller. In particular, T. Burns and T. Schuller, based on the statement of the representative of critical pedagogy P. Freire about the continuity of policy and education, interpret the term «evidence-based research of educational policy» as "honest and open use of current research results for policy making and conscious opt" (Burns, \& Schuller, 2009). They argue that this approach differs from traditional research that seeks to make «informed» decisions, while the latter are mostly focused on developing theoretical approaches and testing hypotheses.

However, comprehending the cited definition, we consider it is necessary to note that both types of research are important for the formation of educational policy, because basic research fills new scientific knowledge with practice-oriented intelligence, expands their methodological tools and deepens terminological field, verifies the reliability of statistics as a rule, makes it impossible to dissociate the empirical-analytical components of research from the normative-creative ones.

According to the analysis of UNESCO's analytical, statistical, reference and recommendation documents, this organization has always combined both presented types of research, providing leadership in promoting new approaches to understanding and elaborating various aspects of adult education. After all, at the national level of any country, politicians and officials are usually reluctant to conduct special research in the formation of educa- tional policy, if they do not provide them with political dividends (Medel-Anonuevo, Torres, \& Desjardins, 2011). However, according to the vast majority of scientists, the current state of research in the education system, not only in the field of adult education, is characterized by a lack of critical analytical developments, which negatively affects its quality. Under these circumstances, the growing influence of civil society institutions and various social movements on the delineation of new directions in the educational policy of adult education and their practical implementation cannot be ignored.

On promoting the role of civil society as well as the definition of clear objectives for of adult education are discussed in the final documents of the UNESCO Sixth International Conference on Adult Education - CONFINTEA VI (UIL, 2010), Belem Framework for Action (2009), UNESCO Recommendations on Adult Learning and Education (2015), as well as in the Third Global Report on Adult Learning and Education (2016) of the UNESCO Institute for Lifelong Learning. These comprehensive complementary documents are intended to assist the international community in developing and implementing a long-term policy of cooperation between governmental and nongovernmental institutions, as well as civil society to: 1) ensure that adult education programs meet the needs of different categories of adults (this process is active in $68 \%$ of UNESCO member-states); 2) adoption of new strategies for the development of adult education (70\% of countries); 3 ) literacy and basic skills learning ( $85 \%$ of countries); 4) establishing a legal framework for the recognition, certification and accreditation of non-formal and informal learning programs (71\% of countries); an increase in adult education programs funding (57\% of countries); development of training and retraining programs for teachers and instructors for adult education $(81 \%$ of countries) (UIL, 2016).

The second, no less important, challenge is the development of effective governance and governance in adult education. According to the Fourth Global Report on Adult Education and Training (2019) of the UNESCO Institute for Lifelong Learning progress in adult education policy-making and management in 152 respondent countries is encouraging, but insufficient, as some countries continue to lag 
behind. For example, two-thirds of the countries reports significant progress in this area since 2015, with 44 countries (almost 30\%) not providing any data on changes in adult learning and post-employment policies in 2015 includes 17 countries located in the AsiaPacific region (47\% of this region). The most important problem in these countries is the lack of development and implementation of new legislation, which increases the risks of not receiving multiple benefits from adult learning and education at both the state and public levels. It is noted that five countries (3\%) reported regression in the development of adult education policies since 2015. We find disappointing the situation around the recognition, validation and accreditation of nonformal and informal learning, as $66 \%$ of countries reported the lowest level of educational policy development. At the same time, threequarters of countries reported significant improvements in the management of adult education and training. Management structures that help implement different policy strategies have significantly strengthened the use of effective coordination and reliance on strong and honest partnerships between different stakeholders in the adult education (UIL, 2019).

As can be seen from the processed national and global reports, UNESCO has challenged to moderate the stakeholders (government agencies, NGOs, adult staff, adult students) activities in the development of adult education at various stages of this process. However, this case is not the sole responsibility of UNESCO. All stakeholders should be responsible for developing and maintaining effective governance to achieve goals at all levels, from global to local (global to regional, subregional to national, subnational to local), and local to global.

One of the most important challenges UNESCO faces today in adult education is effective structures shaping that promote democratic governance (or bottom-up governance), while ensuring the coherence of views for effective communication of all stakeholders and the mobilization of financial and human resources to attain common goals. Experts point to the lack of a global understanding of the concept of lifelong learning formulated by UNESCO, as it seems remote from local realities and therefore requires prior coordination and conscious understanding. This points to the urgent need to strengthen UNESCO's efforts to develop complementary mechanisms for disseminating and discussing the policy concepts by coherent understanding and can be shaped through systematic dialogue and international exchange of diverse national reports. At a minimum, this includes:

- strengthening data collection capabilities (qualitative and quantitative);

- creation of networks and platforms for consultations between key stakeholders on the forefront of joint discussions at the international level;

- providing expert advice based on the study of synthesized research results and reports of international discussions (MedelAnonuevo, Torres, \& Desjardins, 2011).

In our opinion, the key challenge for establishing effective governance in the field of adult learning and education for the near future is the promotion, support and development of these tools and instruments.

Conclusions. Thus, the integrated analysis of key UNESCO documents (Recommendations of the International Conference on Adult Education CONFINTEA $(1985,1997,2003,2009)$, Global Reports on Adult Learning and Education $(2009,2013,2016,2019)$ that outlines the impact of evidence-based research on educational policy in supporting the development of educational policy in adult learning in the global educational environment at the end of the XX and at the beginning of the XXI century.

It is found that the development of adult education is necessary due to the dynamics of social, scientific and technological improvement; changes in the content and nature of work and social activities of people; increased free time and opportunities for its effective use; labor market demands, the main requirements of which are to increase the competence and skills of the professional. Adult involvement in lifelong learning not only encourages meeting own needs, but also ensures self-fulfillment to a free choice of a place, time and a pathway of improvement.

It is proved that since the 1970s up to now UNESCO has played a key role in shaping and disseminating the concept of lifelong learning in education policy. The concept, in essence, involves the restructuring of the existing education system and use of educational perspectives of adults externally the traditional educa- 
tion system in order to influence the development of different social groups and individual development of each person. The world has accumulated considerable meaningful experience in the development of the theory and practice of adult education, which is accumulated, disseminated and implemented through the activities of international organizations on a global scale, including UNESCO. This international organization generates ideas and builds educational policies that are based on reliable statistics and the results of global empirical research.

\section{REFERENCES}

Organizaciya Ob'edinennyh Nacij po voprosam obrazovaniya, nauki i kul'tury. (2002). Rukovodstvo General'noj Konferencii. Parizh: YUNESKO.

Frumin, I. (1998). Vyzov kriticheskoj pedagogiki. Voprosy filosofii, 12, 60.

Furs, V. (2006). Social'naya filosofiya v nepopulyarnom izlozhenii. Vil'nyus: EGU.

Perspektivy: Chetvertaya mezhdunarodnaya konferenciya po obrazovaniyu vzroslyh, Parizh, 19-29 marta 1985 g. (1986). Voprosy obrazovaniya, 3, 116-136.

Burns, T., \& Schuller, T. (2009). Evidence-informed policy in education: New opportunities and challenges. In R. Desjardins, \& K. Rubenson (Eds.), Research of vs research for education policy: In an era of transnational education policy-making (pp. 58-73). Saarbrucken: VDM Verlag.

International Conference on Adult Education. (Ed.). (1997). Fifth international conference on adult education, Hamburg, Germany, July 14-18, 1997: Final report. Paris: UNESCO.

Kellner, D. (2003). Toward a Critical Theory of Education. Journal Democracy \& Nature, 9(1), 51-64.

Medel-Anonuevo, C., Torres, C. A., \& Desjardins, R. (2011). CONFINTEA VI follow-up: the challenges of moving from rhetoric to action. International Review of Education, 57(1-2), 1-8.

Torraco, R. (2005). Writing integrative literature reviews: Guidelines and examples. Human Resources Development Review, 4, 356.

Torres, C. A. (2015). From Hamburg to Belem: the limits of technocratic thinking in adult learning education. International Journal of Lifelong Education, 34(1), 22-31.

UIE. (1997). Adult Education. The Hamburg Declaration. The agenda for the future. Hamburg: UNESCO Institute for Education.

UIL. (2009). CONFINTEA VI: Belem framework for action. Harnessing the power and potential of adult learning and education for a viable future (BFA). Hamburg: UNESCO Institute for Lifelong Leaning.

UIL. (2010). The Sixth International Conference on Adult Education (CONFINTEA VI) "Living and learning for a viable future: the power of adult learning": Final Report. Hamburg: UNESCO Institute for Education.

UIL. (2016). The Third Global Report on Adult Learning and Education (GRALE III). Hamburg: UNESCO Institute for Lifelong Learning.

UIL. (2019). 4 Global Report on Adult Learning and Education: Leave no One Behind: Participation, Equity and Inclusion. Hamburg: UNESCO Institute for for Lifelong Learning

UNESCO. (1976). Recommendation on the development of adult education. Nairobi: UNESCO, $13 \mathrm{p}$.

Наталія Авшенюк, доктор педагогічних наук, старший науковий співробітник, завідувач відділу зарубіжних систем педагогічної освіти і освіти дорослих Інституту педагогічної освіти і освіти дорослих імені Івана Зязюна НАПН України, член Національного агентства із забезпечення якості вищої освіти.

Nataliia Avsheniuk, Doctor of Sciences in Pedagogy, Senior Research Staff, The Head of Department of Foreign Pedagogical and Adult Education at Ivan Ziaziun Institute of Pedagogical and Adult Education of NAES of Ukraine, member of National Agency of Higher Education Quality Assurance.

E-mail: nataliva.avshenyuk@gmail.com ORCID ID 0000-0003-1012-005X 